Article

\title{
Synthesis and Characterization of Polystyrene-Supported Piperazine-Substituted Triazoles by CuAAC and First Evaluation for Metal Ion Extraction
}

\author{
Riadh Slimi ${ }^{1,2}$, Raja Ben Othman ${ }^{1}$, Noomene Sleimi ${ }^{2}$, Abid Ouerghui ${ }^{2,3, *}$ and \\ Christian Girard ${ }^{1, *}$ \\ 1 Unité de Technologies Chimiques et Biologiques pour la Santé, CNRS UMR8258, INSERM U1022, \\ Ecole Nationale Supérieure de Chimie de Paris, PSL Research University, 11 rue Pierre \& Marie Curie, \\ Paris 75005, France; riadhslimi82@yahoo.fr (R.S.); raja_both@yahoo.fr (R.B.O.) \\ 2 Faculté des Sciences de Bizerte, Université de Carthage, Jarzouna, Bizerte 7021, Tunisia; \\ noomene.sleimi@gmail.com \\ 3 Institut Supérieur de Biotechnologie, Avenue Habib Bourguiba, Beja 9000, Tunisia \\ * Correspondence: abid_ouerghui2007@yahoo.fr (A.O.); christian-girard@chimie-paristech.fr (C.G.); \\ Tel.: +33-144-276-748 (C.G.); Fax: +33-144-276-496 (C.G.)
}

Academic Editor: Changle Chen

Received: 4 January 2016; Accepted: 23 March 2016; Published: 10 May 2016

\begin{abstract}
The goal of this work was to synthesize substituted polystyrene for metal extraction and/or depollution by introduction of substituted piperazines as chelatants starting from Merrifield polymer. After transformation of Merrifield's resin in azidomethyl polystyrene, click-chemistry using copper (I)-catalyzed Huisgen's reaction (CuAAC) was performed to prepare different polymers grafted with 1,4-triazoles bearing the piperazines, containing an alkyne as the other counterpart in the CuAAC. The polymers were then first tested for their efficiency to remove various metal ions from neutral aqueous solutions $\left(\mathrm{Fe}^{3+}, \mathrm{Ni}^{2+}, \mathrm{Cu}^{2+}, \mathrm{Zn}^{2+}\right.$ and $\left.\mathrm{Pb}^{2+}\right)$. The polymers were found to extract $\mathrm{Ni}^{2+}$ and $\mathrm{Zn}^{2+}$ with low efficiencies $\leqslant 40 \%$. For Fe ${ }^{3+}$ and $\mathrm{Cu}^{2+}$, the average extraction was around $80 \%$, and for $\mathrm{Pb}^{2+}$ around $50 \%$. The global selectivity for these polymers was found to be in the order of $\mathrm{Fe}^{3+} \geqslant \mathrm{Cu}^{2+}>\mathrm{Pb}^{2+}>>\mathrm{Ni}^{2+}>\mathrm{Zn}^{2+}$.
\end{abstract}

Keywords: Tailor-made polymers; Merrifield resin; click chemistry; piperazine triazoles; metal ion removal

\section{Introduction}

Water pollution by inorganic and organic contaminants is a major concern for water treatment and water stocks management on our planet. These contaminations often occur as a result of human agricultural and industrial activities, but can also be from natural origins, and can be found in all water reservoirs. Metallic ion pollution can have adverse effects on ecosystems and humans, mainly through the drinkable water quality. This kind of pollution is a major concern and solutions to prevent, monitor and treat it are still needed. Metallic cations can be removed from water using clays, natural and synthetic minerals (e.g., zeolites), ceramics and organic polymers bearing the required functions.

For a long time, what we call ion exchange resins, polymers bearing groups chelating a non-toxic metal cation such as sodium or others that can be exchanged with the cation for removal, have been used [1-3]. Several polymers can be made, and substitutions introduced, in order to create hydrophilic [4-7] and hydrophobic polymers [8,9], in order to use them in different applications [10-14]. Ideally, a polymer that can be easily functionalized for a specific application is of great interest. Such polymers can be engineered in a simple way to introduce chelating groups that can complex the metallic ions and find uses in trace detection, depollution or even supported catalysis [15-20]. 
Since our laboratory has been working on metal chelation for supported catalysts, we became interested in the preparation of engineered polymers [21-23]. We decided to introduce substituents on the polymer by using the "click-chemistry" concept and the best example of this approach, namely the copper (I)-catalyzed Huisgen's cycloaddition ("copper (I)-catalyzed azide/alkyne cycloaddition" or $\mathrm{CuAAC}$ [24-29]. The use of CuAAC gives the opportunity to introduce different chelating groups on an azided polymer by selecting substituted alkynes [30-35].

As depicted in Figure 1, the introduced appendages can chelate the metallic cation ("pendant design", $\boldsymbol{a}$ ), but chelation can also occurs from the triazole linkage ("triazole design", $\boldsymbol{b}$ ), or both of these methods ("integrated design", $\boldsymbol{a}, \boldsymbol{b}$ ). The chelation can also be made in mono- or multi-ligand mode, with other chelatants on the polymeric structure.

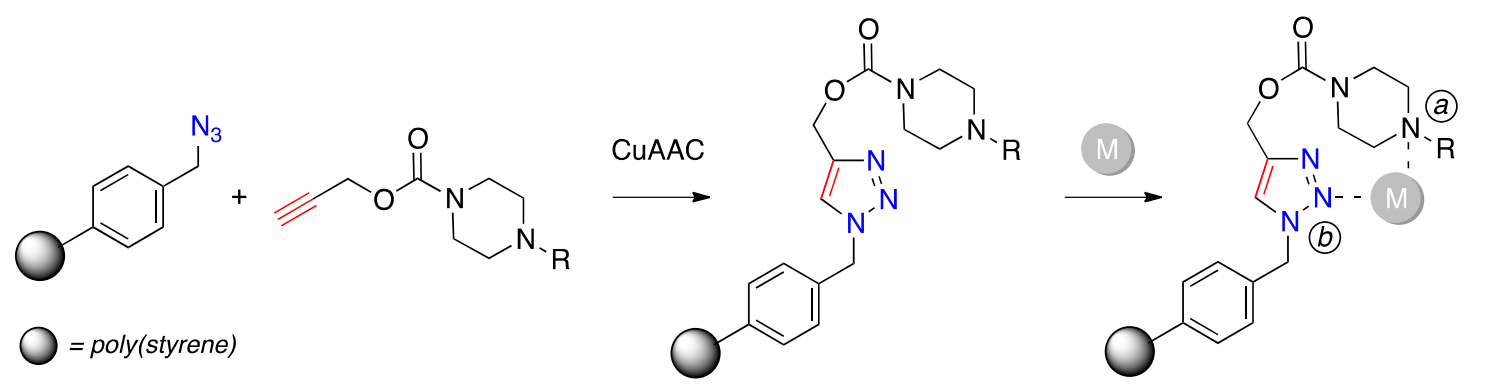

Figure 1. General scheme for the preparation of triazolic-piperazine polymers: Possible chelation methods as pendant $(\mathbf{a})$, triazole $(\mathbf{b})$ and integrated designs $(\mathbf{a}, \mathbf{b})$.

Our previous work was based on amide appendages [23], and we present in this paper the complete synthesis and characterizations of polymer-supported triazole-piperazines using Merrifield polymer (chloromethylated polystyrene) as the starting scaffold, chloride substitution to give azidomethyl polystyrene, followed by $\mathrm{CuAAC}$ with piperazine-substituted alkynes as carbamates of propargyl alcohol (Figure 1). The polymers were then first tested for their ability to extract some metallic cations $\left(\mathrm{Fe}^{3+}, \mathrm{Ni}^{2+}, \mathrm{Cu}^{2+}, \mathrm{Zn}^{2+}\right.$ and $\left.\mathrm{Pb}^{2+}\right)$ from neutral aqueous solutions by atomic absorption spectrometry. The polymers synthesized here were also used in parallel to elaborate a high-throughput evaluation of chelation by conductometry, which has been published elsewhere [36].

\section{Experimental}

\subsection{Materials}

Merrifield polymer (chloromethylated poly-styrene-co-divinylbenzene (1\%), 100-200 mesh, $2.1 \mathrm{mmol} \mathrm{Cl} \cdot \mathrm{g}^{-1}$ ) was purchased from Fluka / Sigma-Aldrich (St-Quentin Fallavier, France), washed alternatively three times with methanol and methylene chloride $\left(10 \mathrm{~mL} \cdot \mathrm{g}^{-1}\right)$ and dried before use. $N$-methylpiperazine $(\mathbf{1 a}, \geqslant 99 \%)$, sodium carbonate ( $\geqslant 98 \%), \mathrm{FeCl}_{3} \cdot 6 \mathrm{H}_{2} \mathrm{O}(97 \%), \mathrm{NiCl}_{2} \cdot 6 \mathrm{H}_{2} \mathrm{O}$ (98\%), $\mathrm{ZnSO}_{4} \cdot 7 \mathrm{H}_{2} \mathrm{O}(98 \%)$ and $\mathrm{CuCl}_{2} \cdot 2 \mathrm{H}_{2} \mathrm{O}(97 \%)$ were issued from the same provider and used as such. Methylene chloride (99.5\%), propargyl chloroformate (96\%), N-ethyl (1b, 98\%), 2-methoxyphenyl (1c, 98\%), 2-pyrimidyl (1d, 98\%), 2-pyridyl (1e, 98\%), benzoyloxycarbonyl (1f, 98\%) and 2-furoyl (19, 97\%) piperazines, and copper (I) iodide 99\%) were provided by Sigma-Aldrich (St-Quentin Fallavier, France) and used as such. Sodium azide (99\%) was supplied by Alfa-Aesar (Schiltigheim, France). Acetonitrile (99.5\%), $\mathrm{Pb}\left(\mathrm{NO}_{3}\right)_{2}$ (99.5\%) were ordered from SDS-Carlo-Erba and used as received. Methanol (97.8\%), and triethylamine (99\%) were bought from Prolabo/VWR (Fontenay sous Bois, France). Tetrahydrofuran (99\%) was from the same source, but distilled from benzophenone sodium ketyl under nitrogen prior to use. Pyridine $(99 \%)$ was ordered from Riedel-de Haën/Sigma-Aldrich (St-Quentin Fallavier, France) and used directly as furnished. 


\subsection{Organic Syntheses}

\subsubsection{Syntheses of Azidomethyl Polystyrene (A) and Piperazine Propargyl Carbamates (2a-2g)}

Organic syntheses (Schemes 1-3, Sections 3.1 and 3.2) were conducted under nitrogen, otherwise stated, using standard methods and procedures. Characterizations were made as described below. Melting points $(\mathrm{mp})$ were measured on a Kofler apparatus after calibration around the observed fusion of the product. Infrared analysis using the attenuated total reflectance technique (ATR/FTIR) was made on a Nicolet FTIR 200 spectrophotometer (Thermo Scientific, Villebon sur Yvette, France) between 4000 and $400 \mathrm{~cm}^{-1}$. Only the main and relevant absorption bands are indicated as vibrations $(v)$ and angular deformations ( $\delta$ ). Nuclear magnetic resonance spectroscopy (NMR) was recorded on a Bruker Avance $300 \mathrm{WB}$ spectrometer (Bruker, Champs sur Marne, France) at $300 \mathrm{MHz}$ for the proton spectra $\left({ }^{1} \mathrm{H}\right)$ and $75.5 \mathrm{MHz}$ for the carbon spectra $\left({ }^{13} \mathrm{C}\right)$. Chemical shifts $(\delta)$ are indicated after calibration on the residual undeuterated solvent peak in parts per million (ppm) and as follow: s (singlet), $\mathrm{d}$ (doublet), $\mathrm{t}$ (triplet), dd (doublet of doublet), $\mathrm{td}$ (triplet of doublet ), $\mathrm{m}$ (multiplet). Coupling constants $(J)$ are given in Hz. High performance liquid chromatography coupled with mass spectrometry (LC-MS) were performed on a Shimadzu LC-10AD VP chromatograph using an Alltima HP C8 $3 \mu$ reverse phase column (Alltech, Carquefou, France, length $=53 \mathrm{~mm}$, internal diameter $=7 \mathrm{~mm}$ ), using a acetonitrile $/ 0.1 \%$ formic acid in water gradient at $1 \mathrm{~mL} \cdot \mathrm{min}^{-1}$ using the following sequence: $0-1 \mathrm{~min}$, $30 \% \mathrm{CH}_{3} \mathrm{CN}$; $1-5 \mathrm{~min} 30 \%$ to $100 \% \mathrm{CH}_{3} \mathrm{CN} ; 5-12 \mathrm{~min}, 100 \% \mathrm{CH}_{3} \mathrm{CN} ; 12-15 \mathrm{~min}, 100 \%$ to $30 \% \mathrm{CH}_{3} \mathrm{CN}$ and $15-20 \mathrm{~min} 30 \% \mathrm{CH}_{3} \mathrm{CN}$. Detection of the species was done using both PDA SPD-M10A VP (diode array, $\mathrm{D}_{2}$ lamp, 190-400 nm) and ELSD-LT (low temperature evaporative light scattering) detectors. Mass spectrometry was performed on a prep LCMS-2010A (liquid chromatograph mass spectrometer) at the end of the HPLC process between $m / z=100$ to 1700 in positive mode by ESI with quadrupole at $5 \mathrm{~V}$ and detector at $1.5 \mathrm{kV}$. Results are given in ELSD purity, retention time $\left(R_{\mathrm{t}}\right)$, and $\mathrm{m} / z$ of the ion.

Synthesis of Azidomethyl Polystyrene (A) (Scheme 1, Section 3.1)

The polymer A was prepared according to literature [37]. Merrifield polymer $\left(2.10 \mathrm{mmol} \mathrm{Cl} \cdot \mathrm{g}^{-1}\right.$, $5.00 \mathrm{~g}, 10.5 \mathrm{mmol} \mathrm{Cl}$ ) was suspended in $50 \mathrm{~mL}$ DMSO and $5.00 \mathrm{~g} \mathrm{NaN}_{3}$ (76.9 mmol, 7.32 eq.) were added. The reaction mixture was slowly magnetically stirred at $70{ }^{\circ} \mathrm{C}$ for $48 \mathrm{~h}$. The cooled mixture was poured in water $(50 \mathrm{~mL})$, filtered on sintered glass and washed eight times with water $(8 \times 25 \mathrm{~mL})$ and finally dried in an oven at $50{ }^{\circ} \mathrm{C}$ overnight. Elemental analysis of the isolated polymer gave $7.63 \% \mathrm{~N}$ and $0.10 \% \mathrm{Cl}$ contents. Calculated substitution efficiency was $99 \%$ and the polymer has a final loading of $1.82 \mathrm{mmol} \mathrm{N}_{3} \cdot \mathrm{g}^{-1}$.

$$
\text { ATR/FTIR: } v=3036,2934,2864,2103\left(v_{\mathrm{N} 3}\right), 1605,1507,1451,1256,816,760,701,547 \mathrm{~cm}^{-1} \text {. }
$$

Synthesis of Propargyl Carbamate Derivatives of Piperazine 2a-g (Scheme 2, Section 3.1)

To a solution of the required $\mathrm{N}$-substituted piperazine $1 \mathrm{a}$ to $\mathbf{1 g}(12.0 \mathrm{mmol})$ in acetonitrile $(45 \mathrm{~mL})$ was added $\mathrm{Na}_{2} \mathrm{CO}_{3}(1.27 \mathrm{~g}, 12.0 \mathrm{mmol}, 1$ eq.). Propargyl chloroformate $(1.42 \mathrm{~g}, 1.17 \mathrm{~mL}, 12.0 \mathrm{mmol}$, 1 eq.) was then added dropwise. The reaction mixture was stirred for $48 \mathrm{~h}$ at room temperature and then filtered and evaporated under vacuum. The resulting carbamates $\mathbf{2 a}-\mathbf{g}$ were sufficiently pure to be used without further purification.

Prop-2-yn-1-yl 4-methylpiperazine-1-carboxylate (2a): $\mathrm{C}_{9} \mathrm{H}_{14} \mathrm{~N}_{2} \mathrm{O}_{2} . \quad M_{\mathrm{W}}=182.21 \mathrm{~g} \cdot \mathrm{mol}^{-1}$. Yield $=92 \%$. Oil. ATR/FTIR: $v=3267,2956,2810,1714,1445,1388,1363,1299,1266,1244,1156$, 1111, 1079, 769, 685, $599 \mathrm{~cm}^{-1}$. ${ }^{1} \mathrm{H}$ NMR (300 MHz, $\left.\mathrm{CDCl}_{3}, \delta\right): 2.28(\mathrm{~s}, 3 \mathrm{H}), 2.36(\mathrm{~s}, 4 \mathrm{H}), 2.45$ $(\mathrm{t}, J=2.41 \mathrm{~Hz}, 1 \mathrm{H}), 3.50(\mathrm{t}, J=5.09 \mathrm{~Hz}, 4 \mathrm{H}), 4.68(\mathrm{~d}, J=2.44 \mathrm{~Hz}, 2 \mathrm{H}) \mathrm{ppm} .{ }^{13} \mathrm{C} \mathrm{NMR}(75.5 \mathrm{MHz}$, $\left.\mathrm{CDCl}_{3}, \delta\right): 43.73,46.09,52.93,54.58,74.56,78.44,154.3$ ppm. LC-MS: ELSD pur. $100 \% ; R_{\mathrm{t}}=1.582 \mathrm{~min}$; $m / z: 183\left([\mathrm{M}+\mathrm{H}]^{+}\right)$.

Prop-2-yn-1-yl 4-ethylpiperazine-1-carboxylate (2b): $\quad \mathrm{C}_{10} \mathrm{H}_{16} \mathrm{~N}_{2} \mathrm{O}_{2} . \quad M_{\mathrm{w}}=196.24 \mathrm{~g} \cdot \mathrm{mol}^{-1}$. Yield $=88 \%$. Oil. ATR/FTIR: $v=3264,2987,2828,2782,1715,1445,1388,1360,1289,1249,1137$, 
1086, 1034, 769, 684, $597 \mathrm{~cm}^{-1} .{ }^{1} \mathrm{H}$ NMR $\left(300 \mathrm{MHz} \mathrm{CDCl}_{3}, \delta\right): 1.06(\mathrm{t}, J=7.21 \mathrm{~Hz}, 3 \mathrm{H}), 2.4(\mathrm{~m}, 7 \mathrm{H}), 3.50$ $(\mathrm{t}, J=5.11 \mathrm{~Hz}, 4 \mathrm{H}), 4.68(\mathrm{~d}, J=4.28 \mathrm{~Hz}, 2 \mathrm{H}) \mathrm{ppm} .{ }^{13} \mathrm{C} \mathrm{NMR}\left(75.5 \mathrm{MHz}, \mathrm{CDCl}_{3}, \delta\right): 11.91,43.88,52.34$, $52.44,52.94,74.48,78.53,154.3$ ppm. LC-MS: ELSD pur. $100 \% ; R_{\mathrm{t}}=1.637 \mathrm{~min} ; m / z: 197\left([\mathrm{M}+\mathrm{H}]^{+}\right.$.

Prop-2-yn-1-yl 4-(2-methoxyphenyl)piperazine-1-carboxylate (2c): $\mathrm{C}_{15} \mathrm{H}_{18} \mathrm{~N}_{2} \mathrm{O}_{3} \cdot M_{\mathrm{W}}=274.31 \mathrm{~g} \cdot \mathrm{mol}^{-1}$. Yield $=99 \% . \mathrm{mp}=105^{\circ} \mathrm{C}$. ATR/FTIR: $v=3250,3080,3006,2893,2834,1686,1596,1506,1444,1363$, $1281,1248,1155,1093,1028,988,747,587 \mathrm{~cm}^{-1} .{ }^{1} \mathrm{H}$ NMR $\left(300 \mathrm{MHz}, \mathrm{CDCl}_{3}, \delta\right): 2.48(\mathrm{t}, J=1.83 \mathrm{~Hz}, 1 \mathrm{H})$, $3.01(\mathrm{~s}, 4 \mathrm{H}), 3.67(\mathrm{t}, J=4.84 \mathrm{~Hz}, 4 \mathrm{H}), 3.86(\mathrm{~s}, 3 \mathrm{H}), 4.72(\mathrm{~d}, J=1.83 \mathrm{~Hz}, 2 \mathrm{H}), 6.99(\mathrm{~m}, 4 \mathrm{H}) \mathrm{ppm} .{ }^{13} \mathrm{C}$ NMR (75.5 MHz, $\left.\mathrm{CDCl}_{3}, \delta\right): 44.19,50.53,52.97,55.44,74.80,78.60,111.5,118.5,121.1,123.5,140.9,152.3,154.3$ ppm. LC-MS: ELSD pur. $100 \% ; R_{\mathrm{t}}=4.845 \mathrm{~min} ; m / z: 275\left([\mathrm{M}+\mathrm{H}]^{+}\right)$.

Prop-2-yn-1-yl 4-(pyrimidin-2-yl)piperazine-1-carboxylate (2d): $\mathrm{C}_{12} \mathrm{H}_{14} \mathrm{~N}_{4} \mathrm{O}_{2} \cdot M_{\mathrm{W}}=246.26 \mathrm{~g} \cdot \mathrm{mol}^{-1}$. Yield $=99 \% . \mathrm{mp}=120^{\circ} \mathrm{C}$. ATR/FTIR: $v=3270,3043,2942,2884,1726,1596,1514,1448,1551,1284$, 1241, 1131, 1095, 1022, $986,960,795,686,498 \mathrm{~cm}^{-1} .{ }^{1} \mathrm{H}$ NMR $\left(300 \mathrm{MHz}, \mathrm{CDCl}_{3}, \delta\right): 2.51(\mathrm{t}, J=2.45 \mathrm{~Hz}$, $1 \mathrm{H}), 3.60(\mathrm{t}, J=5.25 \mathrm{~Hz}, 4 \mathrm{H}), 3.86(\mathrm{t}, J=5.06 \mathrm{~Hz}, 4 \mathrm{H}), 4.70(\mathrm{~d}, J=2.46 \mathrm{~Hz}, 2 \mathrm{H}), 6.55(\mathrm{t}, J=4.76 \mathrm{~Hz}, 1 \mathrm{H})$, $8.34(\mathrm{~d}, J=4.75 \mathrm{~Hz}, 2 \mathrm{H}) \mathrm{ppm} .{ }^{13} \mathrm{C} \mathrm{NMR}\left(75.5 \mathrm{MHz}, \mathrm{CDCl}_{3}, \delta\right): 43.44,43.74,53.15,74.70,78.42,110.4$, 154.5, 157.8, 161.5 ppm. LC-MS: ELSD pur. 100\%; $R_{\mathrm{t}}=4.251 \mathrm{~min} ; \mathrm{m} / z: 247\left([\mathrm{M}+\mathrm{H}]^{+}\right)$.

Prop-2-yn-1-yl 4-(pyridin-2-yl)piperazine-1-carboxylate (2e): $\mathrm{C}_{13} \mathrm{H}_{15} \mathrm{~N}_{3} \mathrm{O}_{2} \cdot M_{\mathrm{W}}=245.27 \mathrm{~g} \cdot \mathrm{mol}^{-1}$. Yield $=99 \% . \mathrm{mp}=92^{\circ} \mathrm{C}$. ATR/FTIR: $v=3261,2956,2873,1703,1601,1487,1441,1571,1289,1242$, 1170, 1123, 1093, 984, 777, 742, 696, $584 \mathrm{~cm}^{-1} .{ }^{1} \mathrm{H}$ NMR (300 MHz, $\left.\mathrm{CDCl}_{3}, \delta\right): 2.52(\mathrm{t}, J=2.44 \mathrm{~Hz}$, $1 \mathrm{H}), 3.60(\mathrm{~m}, 8 \mathrm{H}), 4.77(\mathrm{~d}, J=2.45 \mathrm{~Hz}, 2 \mathrm{H}), 6.69(\mathrm{t}, J=6.06 \mathrm{~Hz}, 1 \mathrm{H}), 7.53(\mathrm{td}, J=7.86 \mathrm{~Hz}, J=2.09 \mathrm{~Hz}$, $2 \mathrm{H}), 8.23(\mathrm{dd}, J=4.76 \mathrm{~Hz}, J=1.02 \mathrm{~Hz}, 1 \mathrm{H}) \mathrm{ppm} .{ }^{13} \mathrm{C} \mathrm{NMR}\left(75.5 \mathrm{MHz}, \mathrm{CDCl}_{3}, 8\right): 43.60,45.02,53.09$, 74.70, 78.44, 107.3, 113.8, 137.7, 148.2, 154.4, $159.1 \mathrm{ppm}$. LC-MS: ELSD pur. $100 \% ; R_{\mathrm{t}}=1.808 \mathrm{~min} ; \mathrm{m} / \mathrm{z}$ : $247\left([\mathrm{M}+2 \mathrm{H}]^{+}\right)$.

Prop-2-yn-1-yl 4-(benzyloxycarbonyl)piperazine-1-carboxylate (2f): $\mathrm{C}_{16} \mathrm{H}_{18} \mathrm{~N}_{2} \mathrm{O}_{4} \cdot \mathrm{M}_{\mathrm{W}}=302.32 \mathrm{~g} \cdot \mathrm{mol}^{-1}$. Yield $=91 \% . \mathrm{mp}=76^{\circ} \mathrm{C}$. ATR/FTIR: $v=3248,2953,2914,2882,1697,1507,1438,1360,1291,1238$, 1110, 990, 952, 919, 868, 758, 591, $557 \mathrm{~cm}^{-1} .{ }^{1} \mathrm{H}$ NMR (300 MHz, $\left.\mathrm{CDCl}_{3}, 8\right): 2.51(\mathrm{t}, J=2.45 \mathrm{~Hz}, 1 \mathrm{H})$, $3.49(\mathrm{~m}, 8 \mathrm{H}), 4.71(\mathrm{~d}, J=2.46 \mathrm{~Hz}, 2 \mathrm{H}), 5.15(\mathrm{~s}, 2 \mathrm{H}), 7.34-7.38(\mathrm{~m}, 5 \mathrm{H}) \mathrm{ppm} .{ }^{13} \mathrm{C}$ NMR $(75.5 \mathrm{MHz}$, $\left.\mathrm{CDCl}_{3}, \delta\right): 43.61,53.19,67.43,74.89,78.28,128.0,128.2,128.6,136.4,154.3,155.1$ ppm. LC-MS: ELSD pur. $96 \% ; R_{\mathrm{t}}=5.213 \mathrm{~min} ; m / z: 343\left([\mathrm{M}+\mathrm{MeCN}]^{+}\right)$.

Prop-2-yn-1-yl 4-(furan-2-carbonyl)piperazine-1-carboxylate (2g): $\mathrm{C}_{13} \mathrm{H}_{14} \mathrm{~N}_{2} \mathrm{O}_{4} \cdot M_{\mathrm{W}}=262.26 \mathrm{~g} \cdot \mathrm{mol}^{-1}$. Yield $=99 \% . m p=102^{\circ} \mathrm{C}$. ATR/FTIR: $v=3238,3129,2947,2889,1718,1631,1589,1497,1432,1355,1286$, 1255, 1191, $1123,1087,1022,769,710,598 \mathrm{~cm}^{-1} .{ }^{1} \mathrm{H}$ NMR $\left(300 \mathrm{MHz}, \mathrm{CDCl}_{3}, \delta\right): 2.51(\mathrm{t}, J=2.45 \mathrm{~Hz})$, $3.6(\mathrm{~m}, 4 \mathrm{H}), 3.82(\mathrm{t}, J=0.33 \mathrm{~Hz}, 4 \mathrm{H}), 4.74(\mathrm{~d}, J=2.45 \mathrm{~Hz}, 2 \mathrm{H}), 6.51(\mathrm{dd}, J=3.49 \mathrm{~Hz}, J=1.78 \mathrm{~Hz}, 1 \mathrm{H})$, $7.06(\mathrm{dd}, J=3.49 \mathrm{~Hz}, J=0.85 \mathrm{~Hz}, 1 \mathrm{H}), 7.51(\mathrm{dd}, J=1.78 \mathrm{~Hz}, J=0.87 \mathrm{~Hz}, 1 \mathrm{H}) \mathrm{ppm} .{ }^{13} \mathrm{C}$ NMR $(75.5 \mathrm{MHz}$, $\left.\mathrm{CDCl}_{3}, \delta\right): 54.64,63.90,86.18,89.19,122.2,127.5,154.9,158.3,164.9,169.7$ ppm. LC-MS: ELSD pur. $100 \% ; R_{\mathrm{t}}=3.993 \mathrm{~min} ; m / z: 263\left([\mathrm{M}+\mathrm{H}]^{+}\right)$.

\subsubsection{Synthesis of Polymer-Supported Triazolic Piperazines 3a-g (Scheme 3, Section 3.2)}

Coupling reactions onto the polymer using CuAAC were conducted accordingly to the general procedure indicated below in round bottom flasks equipped with a reflux condenser. To a suspension of $3.00 \mathrm{~g}$ of azidomethyl polystyrene $\mathbf{A}\left(1.82 \mathrm{mmol} \mathrm{N}_{3} \cdot \mathrm{g}^{-1}, 5.46 \mathrm{mmol} \mathrm{N}_{3}\right)$ in THF $(60 \mathrm{~mL})$ was added $6.30 \mathrm{mmol}$ (1.15 eq.) of the alkyne $(2 \mathrm{a}-\mathrm{g}), 9.00 \mathrm{ml}$ of triethylamine $(6.75 \mathrm{~g}, 66.7 \mathrm{mmol}, 12.2 \mathrm{eq}$. and $2.40 \mathrm{mg}$ of copper (I) iodide $(12.6 \mu \mathrm{mol}, 4 \mathrm{~mol} \%)$. The suspension was slowly stirred at room temperature $72 \mathrm{~h}$. After this time, the complete disappearance of the IR band of the azide of the polymer $\mathbf{A}\left(2103 \mathrm{~cm}^{-1}\right)$ was observed. The resulting polymer was filtered on sintered glass and washed sequentially with $\mathrm{CH}_{2} \mathrm{Cl}_{2}$, pyridine, and $\mathrm{MeOH}$ (60 mL each), the sequential washings were repeated twice. The resulting polymers $3 \mathbf{a}-\mathbf{g}$ were finally dried overnight in an oven at $50{ }^{\circ} \mathrm{C}$.

$1^{\prime}-\left[\left(1^{\prime}, 2^{\prime}, 3^{\prime}\right.\right.$-triazol-4'-yl)methyl 4-methyl-piperazine-1-carboxylate]methyl polystyrene (3a): Yellow powder. $1.50 \mathrm{mmol}$ pipera-zine. $\mathrm{g}^{-1}$. ATR/FTIR: $v=3039,2942,2872,2809,1704,1621,1511,1441$, $1380,1298,1236,1153,1112,1055,1008,820,767,702,551 \mathrm{~cm}^{-1}$. 
1'-[(1',2',3'-triazol-4'-yl)methyl 4-ethylpi-perazine-1-carboxylate]methyl polystyrene (3b): Orange powder. $1.47 \mathrm{mmol}$ piperazi-ne. $\mathrm{g}^{-1}$. ATR/FTIR: $v=3038,2938,2872,2827,1705,1613,1507,1442$, $1382,1289,1249,1134,1060,1028,967,820,765,702,547 \mathrm{~cm}^{-1}$.

1'-[(1',2',3'-triazol-4'-yl)methyl-4-(2-methoxyphenyl)piperazine-1-carboxylate]methyl polystyrene (3c): Brown powder. $1.32 \mathrm{mmol}$ piperazine $\mathrm{g}^{-1}$. ATR/FTIR: $v=3037,2934,2864,1706,1603,1506,1446$, $1383,1287,1245,1126,1087,1033,946,753,702,547 \mathrm{~cm}^{-1}$.

1'-[(1',2',3'-triazol-4'-yl)methyl-4-(pyrimidin-2-yl)piperazine-1-carboxylate]methyl polystyrene (3d): Yellow powder. $1.37 \mathrm{mmol}$ piperazine. $\mathrm{g}^{-1}$. ATR/FTIR: $v=3039,2935,2870,1706,1591,1502,1438$, $1556,1298,1242,1132,1092,1054,981,800,761,703,555 \mathrm{~cm}^{-1}$.

1'-[(1',2',3'-triazol-4'-yl)methyl-4-(pyridin-2-yl)piperazine-1-carboxylate]methyl poly-styrene (3e): Brown powder. $1.37 \mathrm{mmol}$ piperazine. $\mathrm{g}^{-1}$. ATR/FTIR: $v=3037,2938,2864,1705,1601,1485,1437$, $1382,1285,1235,1171,1128,1053,981,837,771,703,534 \mathrm{~cm}^{-1}$.

1'-[(1',2',3'-triazol-4'-yl)methyl-4-(benzyl-oxycarbonyl)piperazine-1-carboxylate $]$ methyl polystyrene (3f): Pale pink powder. $1.27 \mathrm{mmol}$ piperazine $\mathrm{g}^{-1}$. ATR/FTIR: $v=3039,2934,2869,1706,1613,1507,1429$, $1365,1293,1231,1101,1056,1016,980,830,763,703,546 \mathrm{~cm}^{-1}$.

$1^{\prime}-\left[\left(1^{\prime}, 2^{\prime}, 3^{\prime}\right.\right.$-triazol-4'-yl)methyl-4-(furan-2-carbonyl)piperazine-1-carboxylate]methyl polystyrene (3g): Beige powder. $1.34 \mathrm{mmol}$ piperazine $\mathrm{g}^{-1}$. ATR/FTIR: $v=3038,2937,2859,1706,1634,1580,1494$, $1430,1373,1289,1234,1186,1122,1055,1017,843,759,703,547 \mathrm{~cm}^{-1}$.

\subsection{Characterizations by ATR/FTIR of Polymer-Supported Triazolic Piperazines}

Infrared analyses using the attenuated total reflectance technique (ATR/FTIR) were recorded as previously described for organic compounds (vide supra) Results appear in Figure 2, Section 3.1.

\subsection{Metal Ion Extraction Method and Quantification}

Neutral aqueous solutions of metal salts were prepared with $50 \mathrm{mg}$ of $\mathrm{FeCl}_{3} \cdot 6 \mathrm{H}_{2} \mathrm{O}(0.185 \mathrm{mmol})$, $\mathrm{CuCl}_{2} \cdot 2 \mathrm{H}_{2} \mathrm{O}(0.293 \mathrm{mmol}), \mathrm{NiCl}_{2} \cdot 6 \mathrm{H}_{2} \mathrm{O}(0.210 \mathrm{mmol}), \mathrm{ZnSO}_{4} \cdot 7 \mathrm{H}_{2} \mathrm{O}(0.174 \mathrm{mmol})$, and $\mathrm{Pb}\left(\mathrm{NO}_{3}\right)_{2}$ $(0.151 \mathrm{mmol})$ in $1 \mathrm{~L}$ of distilled water.

Aliquots of $250 \mathrm{mg}$ of each polymer (3a: $0.342 \mathrm{mmol}, 3 \mathbf{b}: 0.335 \mathrm{mmol}, 3 \mathbf{c}: 0.302 \mathrm{mmol}, 3 \mathrm{~d}$ : $0.315 \mathrm{mmol}$, 3e: $0.315 \mathrm{mmol}$, 3f: $0.292 \mathrm{mmol}$, $3 \mathbf{g}: 0.307 \mathrm{mmol}$,) were incubated in triplicate with $20 \mathrm{~mL}$ (50 mg. $\mathrm{L}^{-1}, 1 \mathrm{mg}$ of salt) of each metal ion solution $\left(3.70 \mu \mathrm{mol} \mathrm{Fe}{ }^{3+}, 5.87 \mu \mathrm{mol} \mathrm{Cu}{ }^{2+}, 4.21 \mu \mathrm{mol} \mathrm{Ni}{ }^{2+}\right.$, $3.48 \mu \mathrm{mol} \mathrm{Zn}^{2+}$, and $3.02 \mu \mathrm{mol} \mathrm{Pb}{ }^{2+}$ ) at $25^{\circ} \mathrm{C}$ for $24 \mathrm{~h}$. The suspension was then filtered on distilled water prewashed filter paper. Evaluation of the chelated metal was done by concentration measurement by atomic absorption spectrometry on a Perkin Elmer type PinAAcle $900 \mathrm{~T}$, after calibration curves recording for all metals. The results, average of three experiments, were expressed as percentages of extraction of the metal (Figure 3, Section 3.3).

\section{Results and Discussion}

3.1. Synthesis and Characterization of Azidomethyl Polystyrene (A) and Propargyl Carbamate Derivatives of Piperazine $2 a-g$

Following the method of Mioskowski et al. [37], Merrifield's polymer was treated with an excess of sodium azide (7.32 eq.) in DMSO at $70{ }^{\circ} \mathrm{C}$ for $48 \mathrm{~h}$ (Scheme 1). The azidomethyl polystyrene (A) prepared using this method was submitted to elemental analysis, which gave results of $7.63 \%$ for $\mathrm{N}$ and $0.10 \%$ for $\mathrm{Cl}$. The substitution yield was of $99 \%$, and the polymer has a final loading of $1.82 \mathrm{mmol} \mathrm{N}_{3} \cdot \mathrm{g}^{-1}$. The presence of the azido group was confirmed by IR spectroscopy on which its strong characteristic absorption was seen at $2103 \mathrm{~cm}^{-1} v_{\mathrm{N} 3}$ ). 


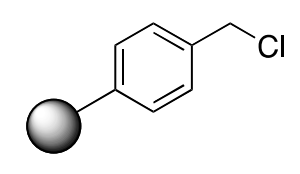

Merrifield's polymer $2.1 \mathrm{mmol} \mathrm{Cl.g}{ }^{-1}$

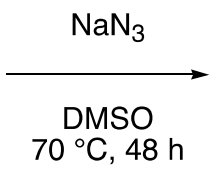

A: azidomethyl PS
$99 \%, 1.82 \mathrm{mmol} \mathrm{N}{ }^{3} \cdot \mathrm{g}^{-1}$

Scheme 1. Preparation of azidomethyl poly-styrene (A) from Merrifield resin.

The required coupling partners for A were prepared using commercially available $N$-substituted piperazines $(\mathbf{1} \mathbf{a}-\mathbf{g})$ and reacting them with propargyl chloroformate in the presence of sodium carbonate in acetonitrile at room temperature for $48 \mathrm{~h}$ (Scheme 2). The corresponding propargyl carbamates 2a-g were obtained in good yields $(88 \%-99 \%)$, without the need of a purification step. Structures of the products 1a-d were confirmed by their characteristic signals in NMR $(c a . \delta=2.5$ (triplet, $\equiv \mathrm{C}-\mathrm{H}$ ) and 4.7 (doublet, $\left.\mathrm{OCH}_{2} \mathrm{C} \equiv \mathrm{CH}\right) \mathrm{ppm}$ in ${ }^{1} \mathrm{H}-\mathrm{NMR} ; 75 / 78(\mathbf{C} \equiv \mathrm{C})$ and $154(\mathbf{C}=\mathrm{O}) \mathrm{ppm}$ in $\left.{ }^{13} \mathrm{C}-\mathrm{NMR}\right)$, IR spectroscopies $\left(\mathrm{ca} .3250\left(v_{\equiv \mathrm{C}-\mathrm{H}}\right)\right.$ and $\left.1700\left(v_{\mathrm{C}=\mathrm{O}}\right) \mathrm{cm}^{-1}\right)$, as well as by LC-MS.

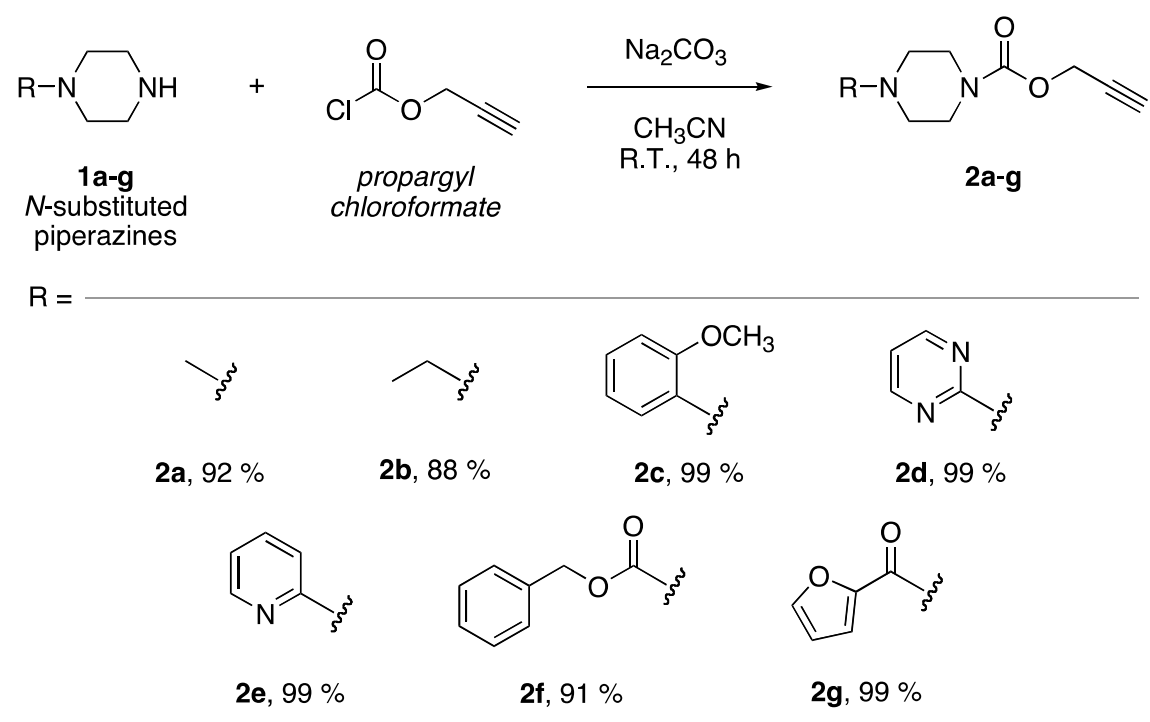

Scheme 2. Synthesis of piperazine propargyl carbamates $\mathbf{2} \mathbf{a}-\mathbf{g}$ from $N$-substituted piperazine $\mathbf{1 a}-\mathbf{g}$ and propargyl chloroformate.

\subsection{Synthesis and ATR/FTIR Analysis of Polymer-Supported Triazolic Piperazines $3 a-g$}

Piperazine propargyl carbamates $\mathbf{2 a - g}$ (1.15 eq.) and azidomethyl polystyrene (A) were coupled together following a CuAAC procedure $\left(4 \mathrm{~mol} \% \mathrm{CuI}\right.$ in the presence of $\left.\mathrm{Et}_{3} \mathrm{~N}\right)$ in order to obtain the corresponding polymer-supported 1,2,3-triazoles-piperazines 3a-g (Scheme 3). The reactions were conducted at room temperature for $72 \mathrm{~h}$, after which time the azide vibration $\left(v_{\mathrm{N} 3}=2103 \mathrm{~cm}^{-1}\right)$ completely disappeared from the resulting polymers. FTIR spectra of the synthesized polymers $3 \mathbf{a}-\mathbf{g}$ did not show any residual vibration band from the azido group $\left(v_{\mathrm{N} 3}, c a .2100 \mathrm{~cm}^{-1}\right)$, as previously mentioned, in either of the alkynes $\left(v_{\equiv \mathrm{C}-\mathrm{H}}, c a .3250 \mathrm{~cm}^{-1}\right)$, as shown in Figure 2 . Characteristic vibration for the carbamate bonds $\left(v_{\mathrm{C}=\mathrm{O}}, c a .1700 \mathrm{~cm}^{-1}\right)$, and other vibrations due to the triazole, the piperazine and the substituents, can be observed when compared to the spectrum of polymer $\mathbf{A}$. The reactions were considered as quantitative based on ATR/FTIR analyses and gave polymers with triazole-piperazine loadings between 1.17 and $1.37 \mathrm{mmol}$ piperazine. $\mathrm{g}^{-1}$ (Table 1). 


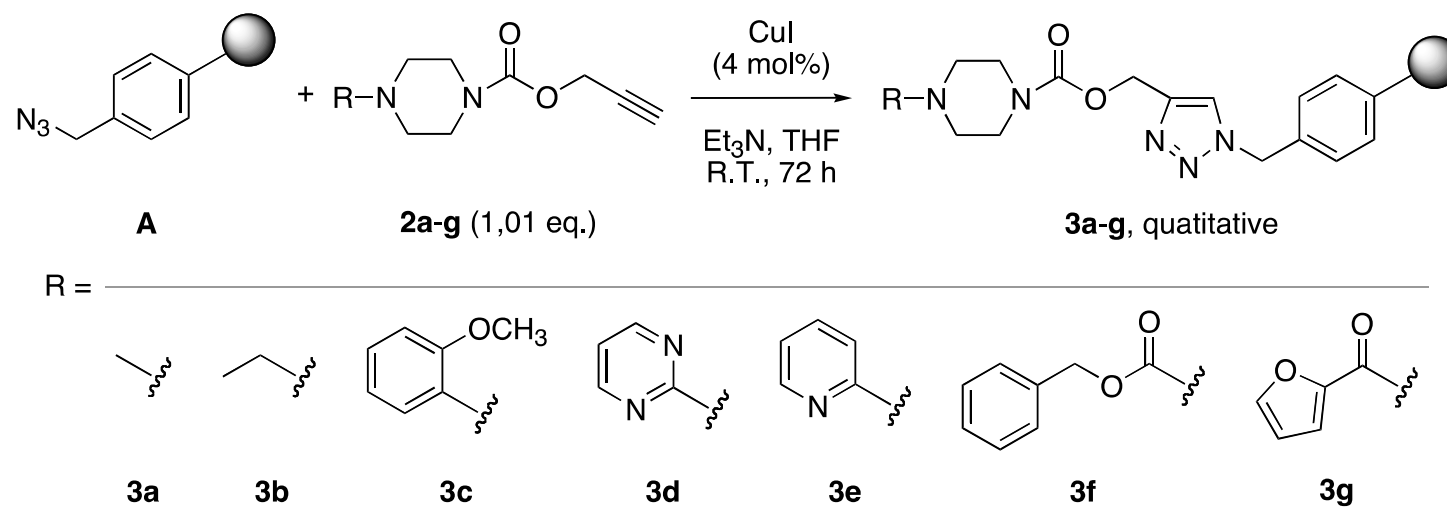

Scheme 3. $\mathrm{Cu}$ (I)-catalyzed Huisgen's reaction of azidomethyl polystyrene (A) with piperazines propargyl carbamates $\mathbf{2 a -} \mathbf{g}$ to obtain the triazolic piperazines polymers $\mathbf{3 a - g}$.

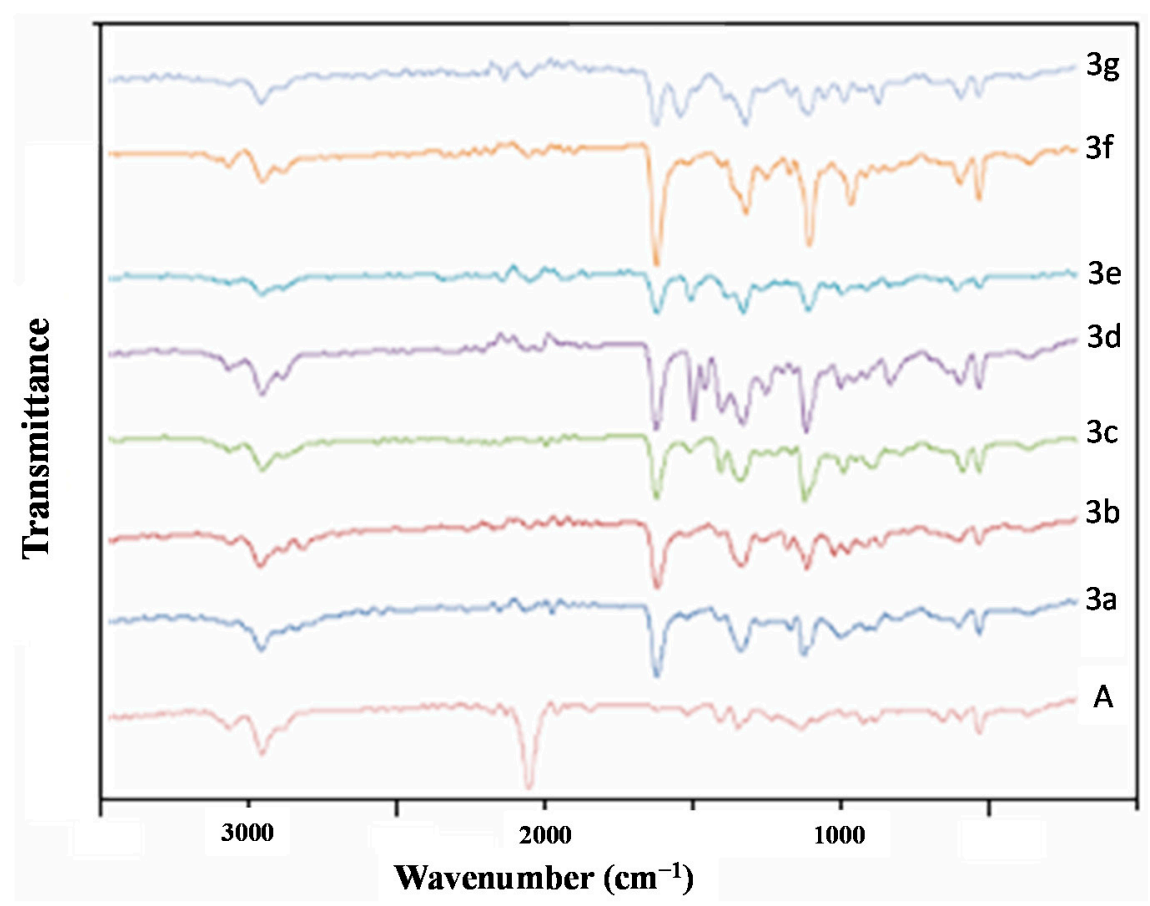

Figure 2. ATR/FTIR spectra of triazolic polymers 3a-g and of the starting azidomethyl polystyrene (A).

Table 1. Masses, substitution and number of millimoles for $250 \mathrm{mg}$ (incubation scale) of the synthesized polymer-supported triazolic piperazines $\mathbf{3 a - g}$.

\begin{tabular}{|c|c|c|c|c|}
\hline Polymer $^{\text {a }}$ & Mass increase (g) ${ }^{b}$ & Total mass (g) & Substitution $\left(\mathrm{mmol}^{\prime} \mathrm{g}^{-1}\right)^{b}$ & $250 \mathrm{mg}(\mathrm{mmol})$ \\
\hline $3 a$ & 0.99 & 3.99 & 1.37 & 0.342 \\
\hline $3 b$ & 1.07 & 4.07 & 1.34 & 0.335 \\
\hline $3 c$ & 1.50 & 4.50 & 1.21 & 0.302 \\
\hline $3 d$ & 1.34 & 4.34 & 1.26 & 0.315 \\
\hline $3 e$ & 1.34 & 4.34 & 1.26 & 0.315 \\
\hline $3 \mathrm{f}$ & 1.65 & 4.65 & 1.17 & 0.292 \\
\hline $3 g$ & 1.43 & 4.43 & 1.23 & 0.307 \\
\hline
\end{tabular}

${ }^{a}$ For structures, see Scheme 3 ; $^{\mathrm{b}}$ Based on a quantitative transformation starting from $3 \mathrm{~g}(5.46 \mathrm{mmol} \mathrm{N}$ ) of polymer $\mathbf{A}$. 


\subsection{Metal Ion Extractions by the Polymer-Supported Triazolic Piperazines $3 a-g$}

After $24 \mathrm{~h}$ incubation on a $250 \mathrm{mg}$ scale $(\sim 0.3 \mathrm{mmol})$ of the polymers (see Table 1$)$ in $20 \mathrm{~mL}$ of $50 \mathrm{mg} \cdot \mathrm{L}^{-1}$ solutions of the salts ( $1 \mathrm{mg}$ of salt, see Section 2.4 for details), the percentages of extraction for each metal were calculated by AAS, each experiment having been carried out in triplicate. The results for each polymer as a function of the metallic cations are presented in Figure 3.

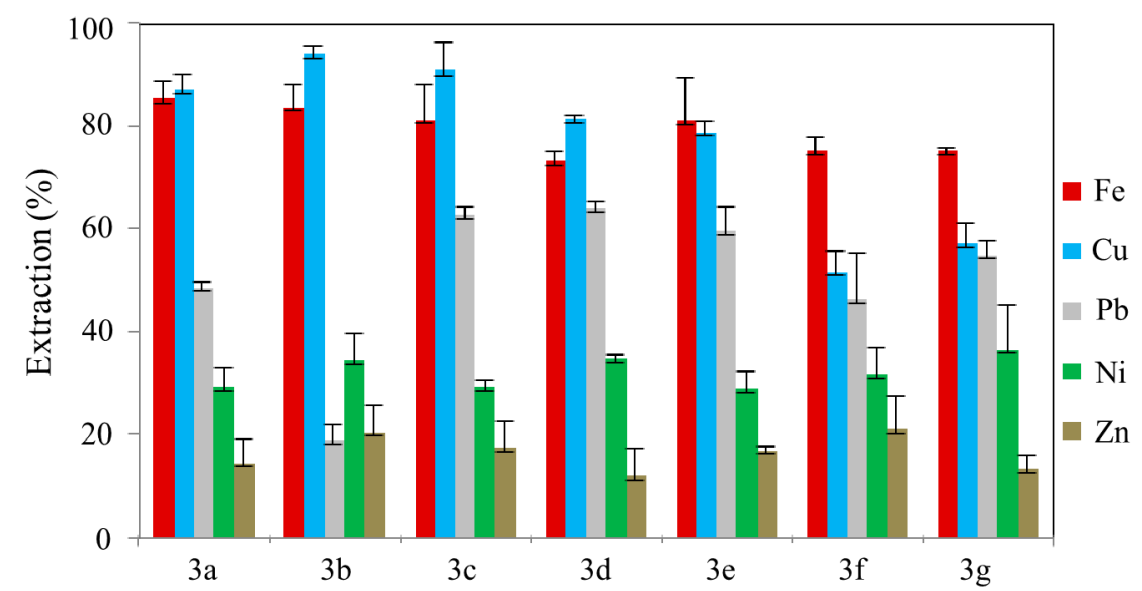

Figure 3. Extraction efficiencies of metal cations by the triazolic piperazine polymers $\mathbf{3 a}-\mathbf{g}$ (by polymer, in triplicate).

Extraction results showed than $\mathrm{Fe}^{3+}$ is well extracted by all the synthesized polymers. The maximum levels of extraction for this metal were obtained with polymers $3 \mathbf{a}(85.40 \% \pm 3.01 \%)$ and $\mathbf{3 b}$ $(83.67 \% \pm 3.87 \%)$.

Other extraction efficiencies were correct, with the minimum encountered with $\mathbf{3 d}$ $(73.14 \% \pm 1.53 \%)$, being in the range of $75 \%-81 \%$, in the following decreasing order: $3 \mathrm{e}(81.16 \%$ $\pm 8.02 \%), 3 \mathrm{c}(81.29 \% \pm 6.26 \%), 3 \mathrm{~g}(75.33 \% \pm 0.19 \%)$, and $3 \mathrm{f}(75.20 \% \pm 2.38 \%)$. The average iron (III) extraction for this series of polymers was around $79 \%$

The second well-extracted metal ion was copper (II), with some higher values than those for $\mathrm{Fe}^{3+}$. Once again, the best extractions were found with polymers $3 \mathbf{a}(87.27 \% \pm 2.52 \%)$ and $3 \mathbf{b}$ $(94.00 \% \pm 1.22 \%)$, together with $3 \mathrm{c}(90.79 \% \pm 5.27 \%)$. The efficiencies for $\mathrm{Cu}^{2+}$ removal were then separated in two groups, with $3 \mathbf{d}(81.64 \% \pm 0.05 \%)$ and $3 \mathbf{e}(78.94 \% \pm 1.61 \%)$ near the first ones, then $3 g(57.37 \% \pm 3.63 \%)$ and $3 f(51.80 \% \pm 3.32 \%)$ being at a medium level. Average extraction for the polymeric series for $\mathrm{Cu}^{2+}$ was near $77 \%$.

For $\mathrm{Pb}^{2+}$ capture from the aqueous solutions by these piperazine-triazolic polymers, it did not follow exactly the same order as for the two previous metals, with an average extraction in the range of $50 \%$. There was an obvious difference between $3 \mathbf{a}(48.53 \% \pm 0.71 \%)$ efficiency being in the average range, and the strong loss for $3 \mathbf{b}(18.93 \% \pm 2.73 \%)$, being the less powerful extracting polymer. Poly(styrenes) $3 \mathbf{d}(64.27 \% \pm 0.81 \%), 3 \mathbf{c}(62.68 \% \pm 1.17 \%)$ and $3 \mathbf{e}(59.67 \pm 4.26 \%)$ were more or less $10 \%$ above the average, and $3 g(54.89 \% \pm 2.44 \%)$ and $3 f(46.28 \% \pm 8.71 \%)$ around it.

For $\mathrm{Ni}^{2+}$, extraction efficiencies were in a narrow distribution around an average value of $32 \%$. None of the studied polymers seemed to retain more of this metallic ion. The results were the following: 3a $(29.37 \% \pm 3.20 \%), 3 \mathbf{b}(34.68 \% \pm 4.59 \%), 3 \mathbf{c}(29.28 \% \pm 1.06 \%), 3 \mathbf{d}(34.98 \% \pm 0.17 \%), 3 \mathbf{e}$ $(28.91 \% \pm 2.89 \%), 3 f(31.87 \% \pm 5.57 \%)$ and $3 g(36.44 \% \pm 8.25 \%)$.

Finally, the least-extracted metal was zinc (II). As for $\mathrm{Ni}^{2+}$, none of the polymers was much better than the low average of $16 \%$. Polymers $3 \mathbf{a}(14.53 \% \pm 4.20 \%), 3 \mathbf{b}(20.45 \% \pm 4.80 \%), 3 \mathbf{c}(17.55 \% \pm 4.58 \%)$, $3 d(12.01 \% \pm 5.09 \%), 3 e(16.97 \% \pm 0.38 \%), 3 f(21.01 \% \pm 6.17 \%)$ and $3 g(13.34 \% \pm 2.39 \%)$ showed a distribution again not very far from the calculated average. 
When looking at all the results, as an average of all polymers, we can observe that the metals that are the best extracted are iron (III) and copper (II), at around $80 \%$, lead (II) is extracted at around $50 \%$, and nickel (II) and zinc (II) at $15 \%-30 \%$. These results suggest that, by selecting the right polymer, a discrimination and selectivity for at least iron (III) and copper (II), and maybe lead (II), can be done over nickel (II) and zinc (II).

Since the polymeric structure differs only by the R substituent on the nitrogen (Scheme 3), a tentative analysis has been done to try to understand the influence of the substituent's nature on the extraction efficiencies. Polymers $\mathbf{3 a}$ and $\mathbf{3 b}$ have an alkyl group on the terminal nitrogen, and are thus amines. For $\mathbf{3 c}-\mathbf{e}$, and aromatic ring is the substituent, and the compounds are aniline derivatives.

Finally, for $\mathbf{3 f}$ and $\mathbf{3 g}$, they include carbonyl linkages, and are in the carbamate and amide families, respectively. Considering only the $\mathrm{R}$ substituent, the availability of the nitrogen electron doublet for chelation should theoretically be in the following order: $\mathbf{3 a}, \mathbf{b}>\mathbf{3} \mathbf{c}-\mathbf{e}>\mathbf{3 f}, \mathbf{g}$. It should be noted, however, that polymer $3 \mathbf{e}$ also includes a pyridyl group, capable of metal chelation.

For iron (III), the nature of the $N$-terminal substituent of the piperazine does not seem to have a determinant effect on the chelation of this metal. Extraction efficiencies are within the same range of $70 \%-85 \%$. Only a small decrease in efficiency can be observed in the previously cited order $(\mathbf{3} \mathbf{a}, \mathbf{b}>\mathbf{3} \mathbf{c}-\mathbf{e}>\mathbf{3 f}, \mathbf{g})$, which may not be that significant.

In the case of $\mathrm{Cu}^{2+}$, a more obvious effect seems to take place, especially for carbamate (3f) and amide (3g) containing $N$-substituents. Polymers $3 \mathbf{a}$ and $\mathbf{b}$ are a little more efficient $(c a .90 \%)$ than $3 \mathbf{c}-\mathbf{e}$ (ca. $80 \%$ ), but there is a more obvious decrease of around $30 \%$ while using polymers $3 \mathrm{f}$ and $\mathbf{3 g}$.

When looking at lead (II) extraction, the effects are more puzzling. $N$-alkyl-substituted polymers $\mathbf{3} \mathbf{a}$ and $\mathbf{3} \mathbf{b}$ are not as efficient as was the case for the two previous metallic ions, with $\sim 50 \%$ and $\sim 20 \%$ extraction, respectively. Aryl-substituted polymers $3 \mathbf{c}-\mathbf{e}$ are better $(60 \%)$, while $\mathbf{3 f}$ and $\mathbf{3 g}$ are going down to the 3 a level.

For $\mathrm{Ni}^{2+}$ and $\mathrm{Zn}^{2+}$, none of the polymers extracted them well. No conclusion can be drawn other than that these polymers are not suitable for their extraction.

The electro-negativities of the substituted nitrogen of the piperazine may partially explain some of the relative extraction efficiencies, at least for iron (III) and copper (II). For lead (II), the alkyl series $(\mathbf{3 a}, \mathbf{b})$ is not really matching the previsions, while the other series do. For $\mathrm{Ni}^{2+}$ and $\mathrm{Zn}^{2+}$, none of the results can give an idea about this influence since they are not well extracted, and the levels are the same for all polymers studied here. These results may indicate that the awaited "pendant design" is not the major mode of complexation encountered in this series. It may be, in part, done by an integrated mode, or it may mainly be driven by the triazole one (Figure 1). Iron (III) and copper (II) are known to be "nitrogen-philic" metals, especially for trinitrogen-/azide-type species. In a previous work, such an effect has been observed [21-23].

Another influence of these terminal $N$-substituents can be the hydrophilic/hydrophobic balance of the polymers. This may explain the access and/or stability of complexes formed between the metal the triazole nucleus. This effect has already been observed in the case of copper (II) and lead (II) in a work on PVC-supported triazolic amides [38].

We have also tried to rationalize the interactions between the polymers and the metal ions based on their electropositivities, ionic radii and water solvation. The extraction efficiencies, based on the metal cation size or electro-positivities, cannot be taken into account since only lead (II) has a superior size and lower electro-positivity when compared to the transition metals having similar radii.

When studying the water solvation of the different metals used here, maybe some explanation can be found when trying to link metal and polymer properties. In Table 2, these are presented in decreasing order of removal of metallic cations. The $\mathrm{pH}$ of the initial solution of the cation $\left(\mathrm{pH}_{\mathrm{i}}\right)$ and the average $\mathrm{pH}$ after extraction by all polymers $\left(\mathrm{pH}_{\mathrm{f}}\right)$ are reported. We can observe that the $\mathrm{pH}$ of the solutions were between 3.2 and 7.4, and that there is no direct link between them and the extraction order. The $\mathrm{pH}$ at which the extraction is performed is important since a speciation can already be performed as a function of the metal ion [39]. In these cases, a " $\mathrm{pH}_{50}$ ", a $\mathrm{pH}$ at 
which $50 \%$ of the cation is extracted, can be calculated. The $\mathrm{pH}_{50}$ values can be correlated in a linear way with another value, the first hydrolysis constant in water $\left(\mathrm{pK}_{1}\right)$, related to the reaction $\mathrm{M}\left(\mathrm{OH}_{2}\right)_{\mathrm{m}}{ }^{\mathrm{n}+}=\mathrm{M}\left(\mathrm{OH}_{2}\right)_{\mathrm{m}-1}(\mathrm{OH})^{(\mathrm{n}-1)+}+\mathrm{H}^{+}[39,40]$. When looking at $\mathrm{pK}$, it can be observed that when the value increases, the extraction of the cation decreases almost accordingly. $\mathrm{pH}_{50}$ is very dependent on the substrate used for cation removal, but always is in linear relation with $\mathrm{pK}_{1}$ as previously mentioned. From published studies, the order of extraction and $\mathrm{pH}_{50} / \mathrm{pK}_{1}$ values increases in the order of $\mathrm{Cu} \geqslant \mathrm{Pb}>>\mathrm{Zn}>\mathrm{Ni}$. From our results, it seems that for $\mathrm{Fe}^{3+}, \mathrm{Cu}^{2+}$ and $\mathrm{Pb}^{2+}$, the solutions as a function of the polymers are between $\mathrm{pH}_{50}$ and $\mathrm{pH}_{90}$. For $\mathrm{Ni}^{2+}$ and $\mathrm{Zn}^{2+}$, the extractions were never excellent, maybe being in a zone between $\mathrm{pH}_{10}$ and $\mathrm{pH}_{40}$. These results thus give the following order of extraction: $\mathrm{Fe}^{3+} \geqslant \mathrm{Cu}^{2+}>\mathrm{Pb}^{2+}>>\mathrm{Ni}^{2+}>\mathrm{Zn}^{2+}$.

Table 2. Average $\mathrm{pH}$ before and after incubation with polymers $\mathbf{3 a}-\mathbf{g}$, and $\mathrm{pK}_{1}$ for each metal ion solution.

\begin{tabular}{ccccc}
\hline Cation & Anion & $\mathbf{p H}_{\mathbf{i}}{ }^{\mathbf{a}}$ & $\mathbf{p H}_{\mathbf{f}}{ }^{\mathbf{b}}$ & $\mathbf{p K}_{\mathbf{1}}{ }^{\mathbf{c}}$ \\
\hline $\mathrm{Fe}^{3+}$ & $\mathrm{Cl}^{-}$ & $3.71 \pm 0.01$ & $3.19 \pm 0.02$ & 2.2 \\
$\mathrm{Cu}^{2+}$ & $\mathrm{SO}_{4}{ }^{2-}$ & $6.90 \pm 0.01$ & $7.06 \pm 0.61$ & 7.6 \\
$\mathrm{~Pb}^{2+}$ & $\mathrm{NO}_{3}{ }^{-}$ & $5.07 \pm 0.01$ & $5.26 \pm 0.59$ & 7.7 \\
$\mathrm{Ni}^{2+}$ & $\mathrm{Cl}^{-}$ & $6.13 \pm 0.01$ & $7.36 \pm 0.62$ & 9.9 \\
$\mathrm{Zn}^{2+}$ & $\mathrm{SO}_{4}{ }^{2-}$ & $6.64 \pm 0.01$ & $5.71 \pm 0.29$ & 9.5
\end{tabular}

a $\mathrm{pH}$ of the salt solution before incubation. Water $\mathrm{pH}$ was $6.66 ;{ }^{\mathrm{b}} \mathrm{pH}$ of the salt solution after incubation;

${ }^{c} \mathrm{pK}_{1}$ values from references included in [40].

All the results and analyses cannot definitively identify the discrete complexation behavior of the metal by the polymers at the solid/liquid interface. However, we were able to obtain results that begin to give a better understanding of the subtle equilibrium between all factors influencing the extraction efficiencies of such polymers.

\section{Conclusions}

In this work, we studied the chemical grafting of piperazine-chelating units onto commercial poly[styrene] (Merrifield's resin) using the CuAAC procedure between the azided polymer and selected piperazine- $N$-propargyl carbamates. The synthesized polymers were characterized by FTIR. They were then tested for their efficiency to extract metallic ions from aqueous solution, including $\mathrm{Fe}^{3+}$, $\mathrm{Ni}^{2+}, \mathrm{Cu}^{2+}, \mathrm{Zn}^{2+}$ and $\mathrm{Pb}^{2+}$. All polymers were found to extract $\mathrm{Fe}^{3+}$ and $\mathrm{Cu}^{2+}$ well.

Most of the polymers were found to have a good extraction potential for $\mathrm{Pb}^{2+}$. None of the polymers were able to extract $\mathrm{Ni}^{2+}$ and $\mathrm{Zn}^{2+}$ with good efficiencies, thus showing certain selectivity when compared to the other studied metallic ions. As an added proof, the extraction efficiencies were studied on 13 metallic cations by a "high-throughput" approach using conductometry [36]. Even if the method was less precise and sensitive, similar average affinities were found for $\mathrm{Fe}^{3+}, \mathrm{Ni}^{2+}$ and $\mathrm{Pb}^{2+}$ (13\%-17\% lower).

In this series, we obtained far better extraction results than with our first series of triazolic polymers, based on poly(styrene) and poly(vinyl chloride) backbones, bearing propargyl amides and propiolic anilides $[23,38]$.

Even if no clear interpretation can be done with the results for the interfacial chelation process, the good extraction properties encourage us to continue polymer modifications using CuAAC in order to find new triazole-linked polymeric complexing agents for depollution, trace detection and catalytic applications [41-47]. Further studies will be reported in due course.

Acknowledgments: This project was financed by Tunisian 05/UR/12-05 and French UMR 8151 CNRS/U1022 INSERM grants. Riadh Slimi is grateful to the Tunisian Ministry of Research and Education for fellowship.

Author Contributions: Abid Ouerghui and Christian Girard conceived and designed the experiments; Riadh Slimi, Raja Ben Othman, Noomene Sleimi and Abid Ouerghui performed the experiments; Abid Ouerghui 
and Christian Girard analyzed the data; Abid Ouerghui, Christian Girard and Noomene Sleimi contributed reagents/materials/analysis tools; Abid Ouerghui and Christian Girard wrote the paper.

Conflicts of Interest: The authors declare no conflict of interest.

\section{References}

1. Rifi, E.H.; Leroy, M.J.F.; Brunette, J.P.; Schloesser-Becker, C. Extraction of copper, cadmium and related metals with poly(sodium acrylate-acrylic acid) hydrogels. Solvent Extr. Ion Exch. 1994, 12, 1103-1119. [CrossRef]

2. Hodgkin, J.H.; Eibl, R. Gold extraction with poly(diallylamine) resins. React. Polym. 1988, 9, $285-291$. [CrossRef]

3. Rivas, B.L.; Klattenhoff, D.; Perich, I.M. Kinetics of uranium sorption from acidic sulphate solutions onto crosslinked polyethyleneimine based resins. 10. Polym. Bull. 1990, 23, 219-223. [CrossRef]

4. Anspach, W.M.; Marinsky, J.A. Complexing of nickel(II) and cobalt(II) by a polymethacrylic acid gel and its linear polyelectrolyte analog. J. Phys. Chem. 1975, 79, 433-439. [CrossRef]

5. Nishide, H.; Oki, N.; Tsuchida, E. Complexation of poly(acrylic acid)s with uranyl ion. Eur. Polym. J. 1982, 18, 799-802. [CrossRef]

6. Pollack, G.H. Water, energy and life: Fresh views from the water's edge. Int. J. Des. Nat. Ecodyn. 2010, 5, 27-29. [CrossRef] [PubMed]

7. Rifi, E.H.; Rastegar, F.; Brunette, J.P. Uptake of cesium, strontium and europium by a poly(sodium acrylate-acrylic acid) hydrogel. Talanta 1995, 42, 811-816. [CrossRef]

8. Wang, X.; Weiss, R.A. A facile method for preparing sticky, hydrophobic polymer surfaces. Langmuir 2012, 28, 3298-3305. [CrossRef] [PubMed]

9. Loret, J.F.; Brunette, J.P.; Leroy, M.J.F.; Candau, S.J.; Prévost, M. Liquid-lipophilic gel extraction of precious metals. Solvent Extr. Ion Exch. 1988, 6, 585-603. [CrossRef]

10. Nghiem, L.D.; Mornane, P.; Potter, I.D.; Perera, J.M.; Cattrall, R.W.; Kolev, S.D. Extraction and transport of metal ions and small organic compounds using polymer inclusion membranes (PIMs). J. Membr. Sci. 2006, 281, 7-41. [CrossRef]

11. Peterson, J.; Nghiem, L.D. Selective extraction of cadmium by polymer inclusion membranes containing PVC and Aliquat 336: Role base polymer and extractant. IJETM 2010, 12, 359-368. [CrossRef]

12. Kebiche Senhadji, O.; Sahi, S.; Kahloul, N.; Tingry, S.; BenAmor, M.; Seta, P. Extraction du Cr(VI) par membrane polymère à inclusion. Sci. Technol. A 2008, 27, 43-50.

13. Guibaud, G.; Baudu, M.; Dollet, P.; Condat, M.L.; Dagot, C. Role des polymeres extracellulaires dans l'adsorption du cadmium par les boues activées role of extracellular polymers in cadmium adsorption by activated sludges. Environ. Technol. 1999, 20, 1045-1054. [CrossRef]

14. Upitis, A.; Peterson, J.; Lukey, C.; Nghiem, L.D. Metallic ion extraction using polymer inclusion membranes (PIMs): Optimising physical strength and extraction rate. Desalin. Water Treat. 2009, 6, 41-47. [CrossRef]

15. Zotti, G.; Zecchin, S.; Schiavon, G.; Berlin, A.; Penso, M. Ionochromic and potentiometric properties of the novel polyconjugated polymer from anodic coupling of 5,5'-Bis(3,4-(ethylenedioxy)thien2-yl)-2,2'-bipyridine. Chem. Mater. 1999, 11, 3342-3351. [CrossRef]

16. Brembilla, A.; Cuny, J.; Roizard, D.; Lochon, P. Un nouveau polymère catalyseur bifonctionnel: Le polyvinyl-5 (6)benzimidazoleméthanethiol Synthèse et catalyse de l'hydrolyse de l'acétate de p-nitrophényle. Eur. Polym. J. 1983, 19, 729-735. [CrossRef]

17. Rhazi, M.; Desbrières, J.; Tolaimate, A.; Rinaudo, M.; Vottero, P.; Alagui, A.; El Meray, M. Influence of the nature of the metal ions on the complexation with chitosan: Application to the treatment of liquid waste. Eur. Polym. J. 2002, 38, 1523-1530. [CrossRef]

18. Kozlowski, C.A.; Walkowiak, W. Applicability of liquid membranes in chromium(VI) transport with amines as ion carriers. J. Membr. Sci. 2005, 266, 143-150. [CrossRef]

19. Kozlowski, C.; Apostoluk, W.; Walkowiak, W.; Kita, A. Removal of Cr(VI), Zn(II) and Cd(II) ions by transport across polymer inclusion membranes with basic ion carriers. Physicochem. Probl. Miner. Process. 2002, $36,115-122$.

20. Toy, P.H.; Janda, K.D. Soluble polymer-supported organic synthesis. Acc. Chem. Res. 2000, 33, 546-554. [CrossRef] [PubMed] 
21. Girard, C.; Önen, E.; Aufort, M.; Beauvière, S.; Samson, E.; Herscovici, J. Reusable polymer-supported catalyst for the [3+2] huisgen cycloaddition in automation protocols. Org. Lett. 2006, 8, 1689-1692. [CrossRef] [PubMed]

22. Jlalia, I.; Beauvineau, C.; Beauvière, S.; Onen, E.; Aufort, M.; Beauvineau, A.; Khaba, E.; Herscovici, J.; Meganem, F.; Girard, C. Automated synthesis of a 96 product-sized library of triazole derivatives using a solid phase supported copper catalyst. Molecules 2010, 15, 3087-3120. [CrossRef] [PubMed]

23. Ouerghui, A.; Elamari, H.; Ghammouri, S.; Slimi, R.; Meganem, F.; Girard, C. Polystyrene-supported triazoles for metal ions extraction: Synthesis and evaluation. Reac. Funct. Polym. 2014, 74, 37-45. [CrossRef]

24. Li, C.; Finn, M.G. Click chemistry in materials synthesis. II. Acid-swellable crosslinked polymers made by copper-catalyzed azide-alkyne cycloaddition. J. Polym. Sci. A Polym. Chem. 2006, 44, 5513-5518. [CrossRef]

25. Tasdelen, M.A.; Yilmaz, G.; Iskin, B.; Yagci, Y. Photoinduced free radical promoted copper(I)-catalyzed click chemistry for macromolecular syntheses. Macromolecules 2012, 45, 56-61. [CrossRef]

26. Liu, Y.; Díaz, D.D.; Accurso, A.A.; Sharpless, K.B.; Fokin, V.V.; Finn, M.G. Click chemistry in materials synthesis. III. Metal-adhesive polymers from $\mathrm{Cu}(\mathrm{I})$-catalyzed azide-alkyne cycloaddition. J. Polym. Sci. A Polym. Chem. 2007, 45, 5182-5189. [CrossRef]

27. Dag, A.; Durmaz, H.; Demir, E.; Hizal, G.; Tunca, U. Heterograft copolymers via double click reactions using one-pot technique. J. Polym. Sci. A Polym. Chem. 2008, 46, 6969-6977. [CrossRef]

28. Opsteen, J.A.; Brinkhuis, R.P.; Teeuwen, R.L.M.; Löwik, D.W.P.M.; van Hest, J.C.M. "Clickable" polymersomes. Chem. Commun. 2007, 3136-3138. [CrossRef] [PubMed]

29. Riva, R.; Schmeits, S.; Jérôme, C.; Jérôme, R.; Lecomte, P. Combination of ring-opening polymerization and "click chemistry": Toward functionalization and grafting of poly( $\varepsilon$-caprolactone). Macromolecules 2007, 40, 796-803. [CrossRef]

30. Löber, S.; Rodriguez-Loaiza, P.; Gmeiner, P. Click linker: Efficient and high-yielding synthesis of a new family of SPOS resins by 1,3-dipolar cycloaddition. Org. Lett. 2003, 5, 1753-1755. [CrossRef] [PubMed]

31. Iskin, B.; Yilmaz, G.; Yagci, Y. ABC type miktoarm star copolymers through combination of controlled polymerization techniques with thiol-ene and azide-alkyne click reactions. J. Polym. Sci. A Polym. Chem. 2011, 49, 2417-2422. [CrossRef]

32. Xue, X.; Zhu, J.; Zhang, Z.; Cheng, Z.; Tu, Y.; Zhu, X. Synthesis and characterization of azobenzene-functionalized poly(styrene)- $b$-poly(vinyl acetate) via the combination of RAFT and "click" chemistry. Polymer 2010, 51, 3083-3090. [CrossRef]

33. Shin, J.A.; Lim, Y.G.; Lee, K.H. Synthesis of polymers including both triazole and tetrazole by click reaction. Bull. Korean Chem. Soc. 2011, 32, 547-552. [CrossRef]

34. Struthers, H.; Mindt, T.L.; Schibli, R. Metal chelating systems synthesized using the copper(I) catalyzed azide-alkyne cycloaddition. Dalton Trans. 2009, 39, 675-696. [CrossRef] [PubMed]

35. Urankar, D.; Pinter, B.; Pevec, A.; de Proft, F.; Turel, I.; Košmrlj, J. Click-triazole N2 coordination to transition-metal ions is assisted by a pendant pyridine substituent. Inorg. Chem. 2010, 49, 4820-4829. [CrossRef] [PubMed]

36. Slimi, R.; Girard, C. "High-throughput" evaluation of polymer-supported triazolic appendages for metallic cations extraction. Metals 2015, 5, 418-427. [CrossRef]

37. Arseniyadis, S.; Wagner, A.; Mioskowski, C. A straightforward preparation of amino-polystyrene resin from Merrifield resin. Tetrahedron Lett. 2002, 43, 9717-9719. [CrossRef]

38. Ouerghui, A.; Elamari, H.; Dardouri, M.; Ncib, S.; Meganem, F.; Girard, C. Chemical modifications of poly(vinyl chloride) to poly(vinyl azide) and "clicked" triazole bearing groups for application in metal cation extraction. React. Funct. Polym. 2016, 100, 191-197. [CrossRef]

39. Eldridge, D.S.; Crawford, R.J.; Harding, I.H. The role of metal ion-ligand interactions during divalent metal ion adsorption. J. Colloid Interface Sci. 2015, 454, 20-26. [CrossRef] [PubMed]

40. Gilson, R.; Durrant, M.C. Estimation of the $\mathrm{pKa}$ values of water ligands in transition metal complexes using density functional theory with polarized continuum model solvent corrections. Dalton Trans. 2009, 10223-10230. [CrossRef] [PubMed]

41. Chan, T.R.; Fokin, V.V. Polymer-supported copper(I) catalysts for the experimentally simplified azide-alkyne cycloaddition. QSAR Comb. Sci. 2007, 26, 1274-1279. [CrossRef]

42. Bergbreiter, D.E.; Hamilton, P.N.; Koshti, N.M. Self-separating homogeneous Copper (I) catalysts. J. Am. Chem. Soc. 2007, 129, 10666-10667. [CrossRef] [PubMed] 
43. Meudtner, R.M.; Hecht, S. Responsive backbones based on alternating triazole-pyridine/benzene copolymers: From helically folding polymers to metallosupramolecularly crosslinked gels. Macromol. Rapid Commun. 2008, 29, 347-351. [CrossRef]

44. Zhang, G.; Wang, Y.; Wen, X.; Ding, C.; Li, Y. Dual-functional click-triazole: A metal chelator and immobilization linker for the construction of a heterogeneous palladium catalyst and its application for the aerobic oxidation of alcohols. Chem. Commun. 2012, 48, 2979-2981. [CrossRef] [PubMed]

45. Astruc, D. Palladium catalysis using dendrimers: Molecular catalysts versus nanoparticles. Tetrahedron 2010, 21, 1041-1054. [CrossRef]

46. Watanabe, W.; Maekawa, T.; Miyazaki, Y.; Kida, T.; Takeshita, K.; Mori, A. Quadruple click: A facile pathway leading to tetrakis(4-(1,2,3-triazolyl)methyl)-ethylenediamine derivatives as a new class of extracting agents for soft metal ions. Chem. Asian J. 2012, 7, 1679-1683. [CrossRef] [PubMed]

47. Movahedi, A.; Moth-Poulsen, K.; Eklöf, J.; Nydén, M.; Kann, N. One-pot synthesis of TBTA-functionalized coordinating polymers. React. Funct. Polym. 2014, 82, 1-8. [CrossRef]

(C) 2016 by the authors; licensee MDPI, Basel, Switzerland. This article is an open access article distributed under the terms and conditions of the Creative Commons Attribution (CC-BY) license (http://creativecommons.org/licenses/by/4.0/). 